DOI: 10.20472/IAC.2019.051.001

KHALDOON ALDAOUD

Yarmouk University, Jordan

\title{
THE IMPACT OF BOARD INDEPENDENCE, WOMEN ON BOARD AND AUDITOR INDEPENDENCE ON THE FRAUD: EVIDENCE FROM JORDANIAN FIRMS
}

\begin{abstract}
:
In developing economies, fraud is an important subject due to the impact on the financial reporting quality. This study discovers the impact of board independence, women on board and auditor independence on the fraud in financial reporting for a sample covers of 86 year observations of industrial firms listed in Amman Stock Exchange from 2015 to 2016. In this study, income smoothing was a proxy for fraud in financial reporting. Using the multiple regression analysis, the results revealed that board independence and auditor independence plays the key role in prevention the fraud in financial reporting. This study concluded that more independent directors would make lower fraud in financial report. This study provides evidence that the provision of NAS by an external auditor positively contributes to fraud in financial reporting. Nevertheless, the outcomes show that the women on board do not have any effect on the fraud in the financial reporting among industrial Jordanian firms. The current study contributes to the existing literature of fraud and stimulates future research about the factors determinants of the fraud in financial reporting in other developing countries.
\end{abstract}

\section{Keywords:}

Fraud, Corporate Governance, External Auditor and Jordanian Firms 


\section{Introduction}

Fraudulent financial statements can take the form of understatement of expenses by costs capitalization that should have been expensed, overstatements of turnover through the recognition of revenues prior to earning them, failure to provide bad and doubtful debts, overstatement of assets, understatement of liabilities, and inadequate disclosure made in the account, among others (Ikharo, 2015). Past studies dedicated to the corporate governance-corporate fraud relationship are generally of the consensus that effective governance will mitigate the opportunity to commit fraud, and they recommended different proxies to measure corporate governance (Chen \& Lin, 2007). In financial statements any type of fraud or dishonest statements can mitigate the credibility of audited financial reports. Therefore, fraudulent activities need to be reduced through the implementation of compliance mechanisms as effective practices of corporate governance (Chaoul, 2016). In addition, financial statement frauds have been an interesting phenomenon among accounting scholar circles, brought on by the commitment of several companies to fraud via the manipulation of financial statements to fool stakeholders. According to Mahesarani and Charir (2016), financial statements that are fraudulent are related to ineffective corporate governance. Additionally, governance is significant in that poor governance has often resulted in financial crisis for each company and sometimes, in economies. Governance refers to the system that directs and controls the company and ensures accountability. Corporate governance is frequently related to the governance of large-listed companies, but governance principles should be employed in companies of all sizes (Lutui \& Ahokovi, 2017).

Generally speaking fraud has been highlighted as a significant issue that has permeated both public and private enterprises in every economy and its negative effects include premature employment termination, court cases, business entities liquidation or corporate failures and serious negative financial effects on the economy of the nation (Ikharo, 2015). Moreover, along with income smoothing, corporate governance has been the current popular issues dominating the global business agenda and scholarly works. As expected, a set of regulatory measures in the form of corporate governance reforms have been created and proposed in the corporate world to minimize the influence of high-profile scandals and failures that stem from income smoothing (Juliana, 2018). In fact, income smoothing is more prominent when the state is the controlling shareholder of listed firms in China as evidenced by Yang, Leing, Tan and Ding (2012). Firms having independent directors have a higher tendency to adopt income smoothing processes and in this background, governance mechanisms (e.g., board of 
directors, supervisory board, audit committee, external auditors and participation of shareholder) are not enough to minimize income smoothing among Chinese firms.

Effective corporate governance primarily aims to protect shareholders from fraud, to promote transparency of information disclosure, ensuring effective control and management accountability so that the companies adhere with the laws (Tanjung, 2015). In fact, a governance system having external laws and regulations and internal mechanisms (mostly arbitrary mechanisms) can bring about the right management application, minimization of issues from information asymmetry, increased trust of shareholders and mitigated income smoothing of management (Mehrazeen \& Mehrtash, 2012). In a related study, In'airat (2015) laid stress on the significance of corporate governance elements in mitigating the fraud level. In particular, internal audit has a key role in mitigating the level of fraud and through the analysis of the effect of the presence, implementation and effectiveness of the governance elements, the outcome showed that their presence and implementation are not enough to mitigate the perceived fraud level. It is only when there is an effective set up of elements that the level of fraud can be decreased. Organizations displaying effective corporate governance practices clearly have benefits. The ever increasing globalization of business and competition among them to acquire capital has led companies to assure stakeholders of their effective management (Lutui \& Ahokovi, 2017).

\section{Literature Background and Hypotheses Development}

\subsection{Board Independence and Fraud in financial reporting}

Board independence has an important role to detect fraud in financial reporting. Prior empirical studies indicate that fraud in financial reporting is significantly influenced by independence members of board of director. Shan, Graves and Ali (2013) found that there is no relationship between number of independent directors and fraud occurrence of Malaysian listed firms (2007 to 2009). Duan and Zhang (2014) used a sample of real estate listed firms penalized for financial fraud for the period of 2007-2013. They showed that the proportions of independent directors are negatively correlated with financial fraud, but not significantly. Donelson, McInnis and Mergenthaler (2015) examined whether governance reforms minimized fraud in financial reporting. Overall, the results revealed that increases independent members on the boards significantly reduced the occurrence of fraud in financial reporting. Chen and Lin (2007) investigated the association between corporate governance and fraud using a sample of 176 listed companies in China for period (2001 to 2005). They found that lower proportion of independent members on board of directors lead to 
suffering companies fraud. However, Mahesarani and Chariri (2016) examined the the effect of corporate governance variables on frauds in financial reporting for Indonesia listed companies that were suspicious for being involvement in frauds for the period from 2008 to 2012 . The study found that there is no significant influence between fraud in financial statement and the independence members of board. Based on the previous results and theoretical discussion that mentioned above, the following hypothesis is suggested;

H1: Independence members of board negatively affect fraud in financial reports.

\subsection{Women on Board and Fraud in financial reporting}

Results on the association between women on board and fraud in financial reporting have shown varied results. Capezio and Mavisakalyan (2016) investigate the association between representation women on board and frauds in financial reporting for 128 listed firms in Australia. They concluded that presence of women on the board of directors is significantly related with reduced the rate of fraud possibility. Wahid (2018) explored the impact of board diversity on financial fraud. The findings reported that the presence of diversity on the boards could have fewer mistakes in financial reporting and resulting involve lower fraud. Abbott, Parker and Presley (2012) examine the effect of presence of female on the boards on the financial restatement. The results of this study indicate that the presence of woman on the board is significantly related with a lower probability incidence of financial restatement. Kamarudin, Ismail and Kamaruzzaman (2018) investigate the association between board member diversity and prospect of fraud in financial reports for sample of Malaysian companies. The findings showed that fraud in financial reports is positively associated with less gender diversity. According to the above arguments the next hypothesis is framed as follows:

H2: Presence of women on board negatively affect fraud in financial reports.

\subsection{Auditor Independence and Fraud in financial reporting}

One of the most significant components in detect the fraud in financial reporting is auditor independence. Prior researches have supported the important role of the independence of external auditor in monitoring and mitigating the fraud in financial reports. Hsiao, Lin, \& Yang (2012) examined the relationship between audit quality and fraud of financial reporting as a measure of earnings management. This study failed to find any significant relationship between fraud of financial reporting and fees paid to external auditors for different services 
provided. Sarwoko and Agoes (2014) examine the impact of auditor's independence, auditor's industry specialization, and procedures of audit to discover fraud for a sample of 50 Indonesian public accounting firms. The outcomes showed a significant influence of auditor's industry specialization and auditor's independence on the employment of audit procedures to discover fraud, and hence have significant influence on the audit quality. Olatunji and Adekola (2017) investigate the effects of auditor experience, independence and, audit fee and size of clients's financial health on the audit quality for Public Accounting companies in Indonesia. On a simultaneously basis, this study found the auditor experience, independence, audit fee and the size of the client's financial health significantly affect the audit quality. On a partial basis, only auditor experience and independence significantly affect the audit quality. Given the previous results which indicate that the independence of external auditor helps to provide a more efficient in detects the fraud, this study presents the following hypothesis.

H3: independence of external auditor negatively affect fraud in financial reports.

\section{Measurements of the Study Variables}

This study measured the board independence (BIND) by the proportion of nonexecutive directors to the total number of directors at the year end. For the women on board (WOB), this study measured the represent the women on board by a dummy variable of (1) if board of directors had women 0 if otherwise. Moreover, this study used a dummy variable to measure the auditor's independence (AIND), with a score 1 if the company purchased non-audit services and 0 if otherwise Regarding to the income smoothing as a proxy of fraud in financial reporting (FRD), this study used Eckel's model (1981) and it's estimated by the following formula:

Eckel Index $=\frac{\text { CVA\%Net Profit }}{\text { CV } \Delta \% \text { Sales }}$

$C V \Delta \%$ Net Profit $=$ Net Profit $_{t}-$ Net $_{\text {Profit }} \mathrm{t}_{\mathrm{t}-1} /$ Net Profit $_{\mathrm{t}-1}$.

$\mathrm{CV} \Delta \%$ Sales $=$ Revenue $_{\mathrm{t}}-$ Revenue $_{\mathrm{t}-1} /$ Revenue $_{\mathrm{t}-1}$.

Eckel Index most generally used to measure income smoothing in several previous studies (Almeida, Sarlo Neto, Bastianello \& Moneque, 2012; Juliana, 2018). Furthermore, when index of Eckel is less than 1 shows that company involved with income smoothing and those higher than 1, indicates non of income smoothing by the company.

\section{Descriptive Analysis}


Table 1 displays maximum value, minimum value and mean value (i.e., descriptive analysis) for 86 firm-year observations of the period of 2015 to 2016 for industrial companies. Based on the sample of 86 industrial companies listed on the Amman Stock Exchange for the period from 2015 to 2016 using secondary data from the annual financial reports, the average of independence of board of director (BIND) is $56.7 \%$ with minimum and maximum .00 and .89 respectively. The average of the presence of women on board (WOB) in the current study is $.093 \%$, which indicates that the women on board are poorly appeared in Jordanian listed firms. For the auditor's independence (AIND), on average, $54.6 \%$ (47) of external auditors of the sample of this study are independent of the company that being audited. With regard of fraud, the descriptive statistics also shows that almost two-thirds of the firms (i.e., 52) in this study perform income smoothing.

Table 1. Descriptive Statistics

\begin{tabular}{lllllc}
\hline & $\mathrm{N}$ & Minimum & Maximum & Mean & Std. Deviation \\
\hline BIND & 86 & .00 & 0.89 & .5678 & .29217 \\
WOB & 86 & .00 & 1.00 & .0930 & .19119 \\
AIND & 86 & .00 & 1.00 & .5465 & .50075 \\
FRD & 86 & .00 & 1.00 & .6047 & .49179 \\
\hline
\end{tabular}

\section{Results of Regression Analysis}

This study aims to investigate the influence of board independence, women on board and auditor independence on the fraud in financial reports on the industrial Jordanian firms. The interaction between the variables is employed by using the following model.

$F R D=\beta_{0}+\beta_{1} B I N D+\beta_{2} W O B+\beta_{3} A I N D+\varepsilon$

Where: $B I N D=$ Board independence, $W O B=$ Women on Board, $A I N D=$ Auditor Independence, $F R D=$ Fraud in financial reporting

As displayed in Table 2, the model of this study is significant $(F=4.907)(\mathrm{Sig} F=$ 0.003 ) and the variables explained $12.1 \%$ of the variation in the fraud in financial reports (Adjusted $R^{2}$ 0.121). As evidenced from Table 2, the result of regression analysis shows that the board independence (BIND) is significant and has a negative direction as predicted with fraud $(\mathrm{t}=-2.409$, Sig $=.018)$. This indicates that the independence of board of director control the management actions and 
help to reduce the fraud in financial reporting. For board diversity, the result shows that the board diversity (WOB) is not significant related to fraud in financial reporting $(\mathrm{t}=-1.242, \mathrm{Sig}=0.218)$. This indicates that the fraud of financial reporting in Jordanian companies is not related the existence or absence women on board. The findings of this study also shows a significant and negative association between auditor independence (AIND) and fraud in financial reporting $(\mathrm{t}=-2.245, \mathrm{Sig}=0.027$. The result refers that the more efficient of the external auditor could have an important role in reduce possibility of fraud in financial reporting.

Table 2: Results of Regression Coefficients

\begin{tabular}{|c|c|c|c|}
\hline Model Summ & & & \\
\hline $\mathrm{N}$ & & & \\
\hline $\mathrm{R}^{2}$ & & & \\
\hline Adjusted $\mathrm{R}^{2}$ & & & \\
\hline F statistic & & & \\
\hline Significance & & & \\
\hline Coefficients: & & & \\
\hline $\begin{array}{l}\text { Independent } \\
\text { Variables }\end{array}$ & $\begin{array}{l}\text { Standardized } \\
\text { Coefficients }\end{array}$ & $t$ & Sig. \\
\hline & Beta & & \\
\hline BIND & -.248 & -2.409 & $.018^{* *}$ \\
\hline WOB & -.133 & -1.242 & .218 \\
\hline AIND & -.240 & -2.245 & $.027^{\star \star}$ \\
\hline
\end{tabular}

\section{Conclusions}

In the context of developing economies, the impact of fraud on the financial reporting quality is indubitable, making fraud a very important topic. The present study examines the effect of board independence, female board members and auditor independence on financial reporting fraud, using 86 year observations of Jordanian industrial listed firms in Amman Stock Exchange from the year 2015 to 2016. The study used income smoothing as a proxy for financial reporting fraud and to analyze the data, the study adopts multiple regression analysis. Based on the findings, board independence auditor independence has a key role in preventing financial reporting fraud. The study concludes that independent directors on the board would assist in minimizing the possibility of a fraudulent 
financial report. According to the obtained findings, NAS provision by an external auditor has a positive contribution to financial reporting fraud and that female board members have no significant effect on fraudulent financial reporting among Jordanian listed firms. This study is expected to contribute to extant literature dedicated to fraud and to urging future studies in examining the determinants of fraud in financial reporting in developing nations.

\section{References}

Abbott, L. J., Parker, S., \& Presley, T. J. (2012). Female board presence and the likelihood of financial restatement. Accounting Horizons, 26(4), 607-629.

Almeida, J. E. F. D., Sarlo Neto, A., Bastianello, R. F., \& Moneque, E. Z. (2012). Effects of income smoothing practices on the conservatism of public companies listed on the BM \& FBOVESPA. Revista Contabilidade \& Finanças, 23(58), 65-75.

Capezio, A., \& Mavisakalyan, A. (2016). Women in the boardroom and fraud: Evidence from Australia. Australian Journal of Management, 41(4), 719-734.

Chaoul, L. F. (2016). Effects of corporate governance on fraud prevention.(c2016) (Doctoral dissertation, Lebanese American University).

Chen, L., \& Lin, W. (2007). Corporate governance and fraud: evidence from China. Corporate ownership and control, 4(3), 139-145.

Donelson, D. C., Mclnnis, J. M., \& Mergenthaler, R. (2015). The effect of governance reforms on financial reporting fraud.

Duan, Y., \& Zhang, X. (2014). Impacts of Board Characteristics of the Listed Companies in Financial Fraud. In ICCREM 2014: Smart Construction and Management in the Context of New Technology (pp. 1001-1007.

Eckel, N. (1981). The income smoothing hypothesis revisited. Abacus, 17(1), 2840.

Hsiao, F. D., Lin, J. W., \& Yang, J. S. (2012). An Empirical Analysis of The Effect of Audit Quality On Financial Reporting Fraud. Corporate Ownership \& Control, 391. 
Ikharo C.O. (2015). The Impact of Auditor's Tenure on Quality Audit Report. Research Journal of Finance and Accounting.6, (1).

In'airat, M. (2015). The Role of Corporate Governance in Fraud Reduction-A Perception Study in the Saudi Arabia Business Environment. Journal of Accounting \& Finance (2158-3625), 15(2).

Juliana, I. M (2018) Corporate Governance and Income Smoothing in the Nigerian Deposit Money Banks. International Journal of Business \& Law Research 6(1):27-38.

Kamarudin, K. A., Ismail, W. A. W., \& Kamaruzzaman, A. A. (2018). Board Members Diversity and Financial Statements Fraud: Malaysian Evidence. In State-of-the-Art Theories and Empirical Evidence (pp. 165-183). Springer, Singapore.

Lutui, R., \& Ahokovi, T. A. (2017). Financial fraud risk management and corporate governance.

Mahesarani, D. S., \& Chariir, A. (2016). Corporate governance and financial statement frauds: Evidence from Indonesia. The 1st International Conference on Economics, Education, Business and Accounting (ICEEBA)

Mehrazeen, A. R., \& Mehrtash, M. (2012). Corporate Governance Mechanism and Income Smoothing in Iran. J. Basic. Appl. Sci. Res, 2(4), 3188-3194.

Olatunji, O. C., \& Adekola, D. R. (2017). The Roles of Auditors in Fraud Detection and Prevention in Nigeria Deposit Money Banks: Evidence from Southwest. European Scientific Journal, ESJ, 13(31).

Sarwoko, I., \& Agoes, S. (2014). An empirical analysis of auditor's industry specialization, auditor's independence and audit procedures on audit quality: evidence from indonesia. Procedia-Social and Behavioral Sciences, 164, 271281.

Shan, Y. G., Graves, C., \& Ali, H. H. (2013). Effect of board composition and ownership characteristics on fraud: Evidence from Malaysian listed companies. South East Asia Research, 21(2), 323-342.

Tanjung, M. (2015). The Role of Good Corporate Governance in Minimizing Earning Management to Increase Value of Firm. International Journal of Scientific \& Technology Research, 4(9), 21-27.

Wahid, A. S. (2018). The Effects and the Mechanisms of Board Gender Diversity: Evidence from Financial Manipulation. Journal of Business Ethics, 1-21. 
Yang, C. Y., Leing Tan, B., \& Ding, X. (2012). Corporate governance and income smoothing in China. Journal of Financial Reporting and Accounting, 10(2), 120-139. 